\section{GRIFFING: A SAS Macro Implementing Griffing's Analysis of Diallel Crossing Systems}

\section{Stephen B. Linda}

Department of Statistics, University of Florida, Institute of Food and Agricultural Sciences, P.O. Box 110560, Gainesville, FL 32611-0560

Additional index words. combining ability

Diallel crossing systems are often used to determine combining ability in horticultural breeding studies. The SAS (SAS Inst., Cary, N.C.) macro GRIFFING performs analyses of diallel crosses, based on Griffing (1956). Eight

Received for publication 10 Feb. 1992. Acceptedfor publication 1 Oct. 1992. Florida Agr. Expt. Sta. Journal Series no. R-02165. The cost of publishing this paper was defrayed in part by the payment of page charges. Under postal regulations, this paper therefore must be hereby marked advertisement solely to indicate this fact. different analyses, which resulted from four different diallel crossing systems and which consider effects as either fixed or random, are available. Griffing defined crossing systems (methods) according to whether parental inbreds, the reciprocal $F_{1} s$, or both were included in the experiment (Table 1).

Output from GRIFFING consists of an analysis of variance table of combining ability effects. Additionally, if effects are fixed, a table of effects estimates is printed. If effects are random, the variance components estimates, and their approximate SES, are printed.
Included crosses

\begin{tabular}{lcc}
\cline { 2 - 3 } Method & Parents & Reciprocals \\
\hline 1 & Yes & Yes \\
2 & Yes & No \\
3 & No & Yes \\
4 & No & No \\
\hline
\end{tabular}

GRIFFING was programmed in a DATA step, using the SAS Macro Language (SAS Institute, 1987) to pass parameters. It must be used as part of an SAS system (SAS Institute, 1988) program.

To obtain GRIFFING and a user's manual, send an IBM-compatible formatted diskette and a large, self-addressed stamped envelope to S.B.L.

\section{Literature Cited}

Griffng, B. 1956. Concept of general and specific combining ability in relation to diallel crossing systems. Austral. J. Biol. Sci. 9:463-493.

SAS Institute. 1987. SAS guide to macro processing. Version 6, first ed. SAS Institute, Inc., Cary, N.C.

SAS Institute. 1988. SAS language guide for personal computers. Release 6.03 ed. SAS Institute, Inc., Cary, N.C. 